\title{
Research of COD and BOD Removal Efficiency in Tempeh Industrial Wastewater Treatment using Aerated Activated Sludge
}

\author{
L.Nurdini, Hendriyana, W.G. Nur Asti .D, A. Febriyani Putri
}

\begin{abstract}
Tempeh is the most popular food in Indonesia. The process of making tempeh requires a lot of water. The preliminary analysis of tempeh wastewater showed that the value of COD, BOD and $\mathrm{pH}$ are $26693 \mathrm{mg} / \mathrm{l}, 11204 \mathrm{mg} / \mathrm{l}$ and 3,99. This results actually do not meet the Minister of Environment regulation No.5 (2014) about quality standard of wastewater treatment for industry. The quality standard for $C O D, B O D$ and $P H$ for tempeh wastewater are 100-300 $\mathrm{mg} / \mathrm{l}, 50-150 \mathrm{mg} / \mathrm{l}$, and 6-9. So, the tempeh industrial wastewater must be processed before being discharged into the environment. The aim of this study is to determine the activated sludge ability to reduce COD, $B O D$, and also $\mathrm{pH}$ value in tempeh industrial wastewater. Tempeh industrial wastewater treatment carried out in aerated batch reactor using wastewater composition $10 \%$, 15\%, and $25 \%$ (v/v) of tempeh wastewater in $500 \mathrm{ml}$ as a research variables. The wastewater while the hidraulic retention time is 48 hours. The highest COD, BOD removal efficiency occured at $25 \%(v / v)$ wastewater composition each for 74,58\%, 79,27\%. The COD and BOD concentration after treatment are 7625,79 $\mathrm{mg} / \mathrm{l}$ and 4555,7 $\mathrm{mg} / \mathrm{l}$. And $\mathrm{pH}$ at $25 \%(\mathrm{v} / \mathrm{v})$ wastewater composition is 6,92. $\mathrm{pH}$ value after treatment meet quality standard of industrial wastewater from Minister of Environment regulation No.5 (2014), but COD and BOD do not meet the standards.
\end{abstract}

Keywords : COD, BOD, Activated sludge

\section{INTRODUCTION}

T empeh is an Indonesian traditional food made from soybeans. Indonesian people consume tempeh 7,47 kilograms/capita/ years in average [1]. The total domestic demand for soybean is growing every year, this is proportional to the growing number of tempeh producer in Indonesia. Indonesia is currently the largest tempeh producer in the world, $80 \%$ of soybeans demand used for tempeh production and the rest of them used for other food needs. This causes Indonesia become the largest soybean market in asia [2]. Water use in tempeh production is very important, especially in washing process, boiling process, and soaking process of soybean [3]. This series of the processes produced tempeh wastewater. If, it does not treated properly, it may

Revised Manuscript Received on January 10, 2020.

* Correspondence Author

Lulu Nurdini*, Universitas Jenderal Achmad Yani, Indonesia. Email: lulu.nurdini@lecture.unjani.ac.id

Hendriyana, Universitas Jenderal Achmad Yani, Indonesia. Email: hendriyana@lecture.unjani.ac.id

W.G Nur Asti .D, Universitas Jenderal Achmad Yani, Indonesia

A. Febriyani Putri, Universitas Jenderal Achmad Yani, Indonesia caused water pollution. Furthermore, it produces smell odors and bothering human activity.

Generally, tempeh wastewater has a high BOD value. In this research, tempeh wastewater sample taken from one of tempeh home industry in Cimahi. It produces 250 liters tempeh wastewater everyday. The source of tempeh wastewater comes from soybean soaking process, because this proces is one of the processes that produced high BOD value. Table-I showed the characteristic of tempeh wastewater from those industry. All the tempeh wastewater parameter exceeded the wastewater quality standard in the Regulation of Indonesian Ministry of Environment No.5 2014 [4]. According to the Table 1, it is strongly recomended to treat the tempeh wastewater before it can be discharged into the enviroment.

The aim of this research was to analyzed BOD removal efficiency, COD removal efficiency, and MLSS concentration in tempeh wastewater treatment using activated sludge. Activated sludge is one of the most widely used conventional wastewater treatment technologies to treat wastewater with high organic substance [5]. Organic substance in wastewater are treat biologically by microbial activity grow suspended in the reactor. There are two mechanism for treating sludge with activated sludge, the first is physical-chemical absorption, the second is the process of absorbing organic pollutants into biomass particle become $\mathrm{CO}_{2}$ and $\mathrm{H}_{2} \mathrm{O}$ by microbial activity [6].

Table- I: Tempeh Wastewater Characteristic

\begin{tabular}{|c|l|c|c|}
\hline No & \multicolumn{1}{|c|}{ Parameter } & $\begin{array}{c}\text { Wastewater from } \\
\text { Soybean Soaking } \\
\text { Process }\end{array}$ & $\begin{array}{c}\text { Standar } \\
\text { Quality of } \\
\text { Wastewater }\end{array}$ \\
\hline 1 & BOD (mg/l) & 11.204 & 50 \\
\hline 2 & COD (mg/L) & 26.693 & 100 \\
\hline 3 & TSS (mg/L) & 356 & 200 \\
\hline 4 & pH & 3.99 & $6-9$ \\
\hline
\end{tabular}

\section{MATERIALS AND METHODS}

Tempeh wastewater, activated sludge, glucose, NPK fertilizer, urea fertilizer, reactor, aerator dan rotameter. Tempeh wastewater concentration 5\%, 10\% dan 25\% from $500 \mathrm{~mL}$ activated sludge.

\section{A. Activated Sludge Acclimization}

Activated sludge is prepared before being used in the treatment process. Seeding is carried out for three weeks by providing glucose, NPK fertilizer, and urea as nutrients. The first thing to

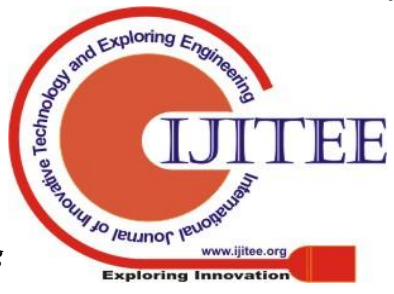


prepare is to make the liquid medium, this made from glucose, NPK fertilizer, and urea dissolved in $1800 \mathrm{~mL}$ aquadest and $200 \mathrm{~mL}$ tempeh wastewater.

The second, adding 10 grams sediment and the liquid medium into reaktor, and then aerated.

In this research, the equipment experiment of tempeh wastewater treatment showed in Figure 1. The experiment carried out in batch operation. The ratio of tempe wastewater and activated sludge are $5 \%, 10 \%$, and $25 \%$ from activated sludge volume. Feeding is entered gradually during the experiment. The air continously inserted into the reactor through an aerator. The rotameter installed to control the rate of air entering the reactor. The hidraulic retention time in the reacor is 48 hours. The parameter analysis of tempeh wastewater treatment is BOD, COD, and MLSS.

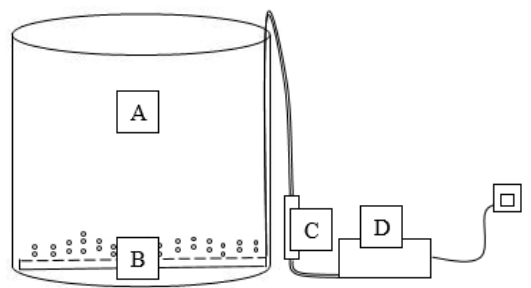

Fig. 1. The Eaquipment of Experiment : (A) Reactor, (B) Aerator Stone, (C) Rotameter, (D) Aerator

\section{RESULT AND DISCUSSION}

\section{A. Activated Sludge Acclimization}

Before treating tempeh wastewater, the activated sludge must be growed. Seeding carried out for three weeks by providing glucose, NPK fertilizer, and urea fertilizer for growth nutrition. Figure 1 shows an increase in MLSS concentration during the seeding process for three weeks (21 days). In the third week the MLSS concentration reached $10100 \mathrm{mg} / \mathrm{L}$. Seeding process is carried out under neutral $\mathrm{pH}$ condition [5]. This provides environmental conditions that support th egrowth of activated sludge. The air flow rate 1.1 $\mathrm{lpm}$, and the $\mathrm{F} / \mathrm{M}$ ratio 0,21 . The $\mathrm{F} / \mathrm{M}$ ratio in the process is in the range which indicate the microbes are in a hungry condition, thus increasing the efficiency of wastewater treatment [5].

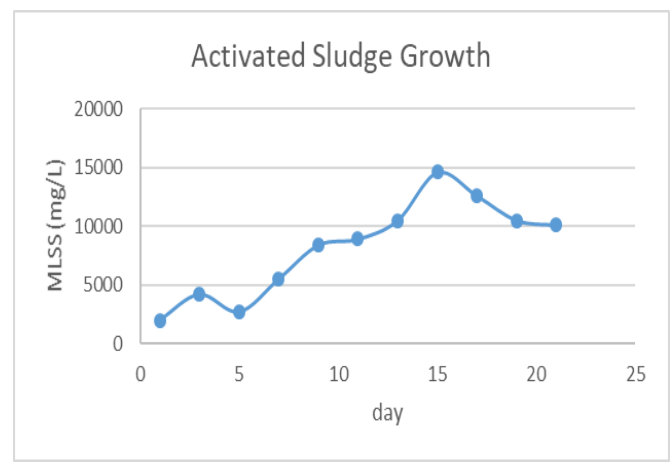

Fig. 2. Activated Sludge Growth

\section{B. Biological Oxygen Demand (BOD)}

The BOD parameter analysis of untreatead tempeh wastewater was $20851,14 \mathrm{mg} / \mathrm{L}$. After treating the tempeh wastewater using aerated activated sludge, BOD concentration decreased (Figure 3). An increased in feed concentration showed an increase in BOD removal. The tempeh wastewater is gradually added into the aerated reactor. It is affect the wastewater treatment process, the MLSS in aeration reactor increasing and so the BOD removal efficiency increased [8]. The result showed BOD concentration exceeded the quality standard by Regulation of Indonesian Ministry of the Environment No.5 2014. This happens because of the lack of contact time between tempeh wastewater and microbes in the reactor [9].

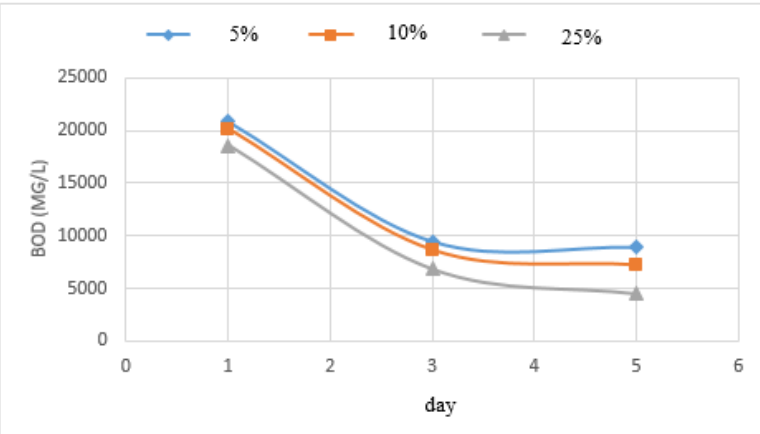

Fig. 3. Biological Oxygen Demand (BOD) Removal

\section{Chemical Oxygen Demand (COD)}

COD shows the oxygen contain to oxydized organic compound in tempeh industrial wastewater chemically [10]. Typically, the COD value is higher than BOD value because a lot of organic compound unoxidized biolologically [5]. Figure 4 showed sharp decline of COD degradation at the first time of the treatment. At this condition, the microbes convert the organic compound into new cells, $\mathrm{CO}_{2}$, and also $\mathrm{H}_{2} \mathrm{O}$. COD effeciency at $5 \%, 10 \%$, and $25 \%$ feed are $56.33 \%$, $62.96 \%$, and $74,58 \%$.

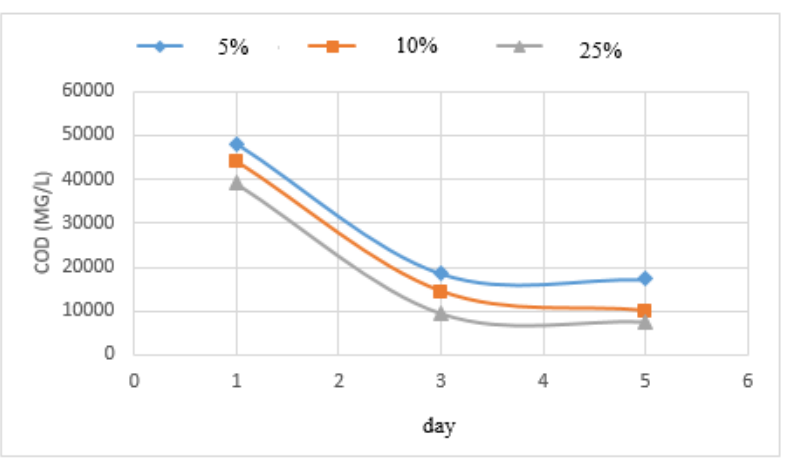

Fig. 4. Chemical Oxygen Demand (COD) Removal

\section{Mixed Liquor Suspended Solid (MLSS)}

Mixed Liquor Suspended Solid (MLSS) shows the concentration of organic compound and microbes in the reactor [5]. Figure 5 shows at the third day of the treatment a shock load occur. Shock load occur due to changes in the reactor condition after adding 
tempeh wastewater. This result a large number of contaminant in the wastewater undegraded completely thus reducing the ability of the microbes to degrade the contaminant in tempeh wastewater. This is because the microbe takes time to degrade the organic compound in the tempeh wastewater. The MLSS value at $5 \%, 10 \%$ and $25 \%$ feed variation were $9500 \mathrm{mg} / \mathrm{L}, 8600 \mathrm{mg} / \mathrm{L}$, and $9200 \mathrm{mg} / \mathrm{L}$.

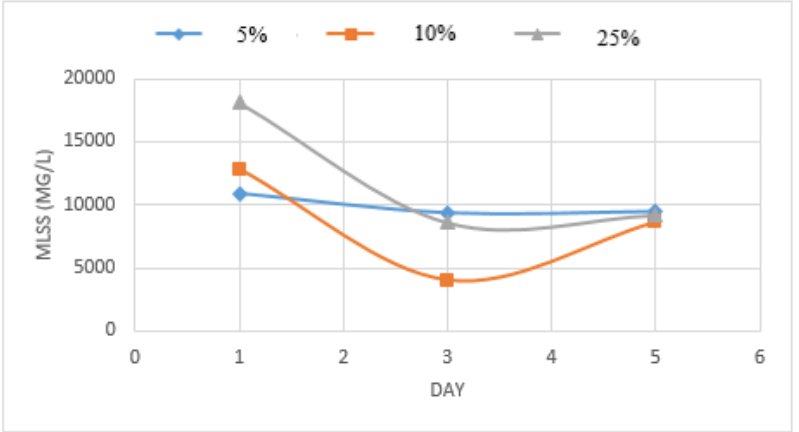

Fig. 5. Mixed Liquor Suspended Solid (MLSS) Concentration

\section{CONCLUSION}

The results from experiments showed the highest BOD removal efficiency and COD removal efficiency at $25 \%$ feed of tempeh industrial wastewater $74.58 \%$ and $79.27 \%$, and MLSS concentration at this point is $9200 \mathrm{mg} / \mathrm{L}$. This result the exceeded the quality standard by Regulation of Indonesian Ministry of the Environment No.5 2014.

\section{ACKNOWLEDGMENT}

This research funded by LPPM Universitas Jenderal Achmad Yani (UNJANI).

\section{REFERENCES}

1. Sabarella. Komalasari, Wieta.B. Wahyuningsih, Sri. N, Metha Herwulan. Mnanurung, Megawati. Sehusman. Rinawati. Supriyati, Yani., (2017), Buletin Konsumsi Pangan, 8, 1, 37.

2. Badan Standar Nasional, (2012), Tempe : Indonesia's offering for the world

3. Purwanti, Ipung Fitri. Simamora, Dorlinca. Kurniawan, Setyo Budi., (2018), International Journal of Civil Engineering and Technology (IJCIET), 9, 4, 1166-1172.

4. Minister of the environment, (2014), Jakarta.

5. Metcalf \& Eddy. (2004), Transport Processes and Unit Operations, Prentice Hall International, Inc., United State of America.

6. Titiresmi, (2009), Seeding and acclimatization process of microorganisms in activated sludge from candy wastewater plant, Jurnal Rekayasa Lingkungan (JRL), 5, 2, 139-144.

7. Said, Nusa Idaman., (2008), Domestic waste treatment in Jakarta “ An overview of problems, strategies and processing technologies:

8. Titiresmi., (2010), Reduction of cod levels in the candy industry wastewater using activated sludge reactor, Jurnal Teknik Lingkungan, 11 , 1, 1-6.

9. Abdullah, Herkules. Simatupang, Halim. Aryeni. Gunawan, Roni (2018), The influence of BOD wastewater levels through the aerator, Prosiding SNEI 4.0, $455-459$.

10. Nurdini, L. Setiadi, Tjandra., (2015), High Salinity Domestic wastewater treatment using SANI process using Modified Anaerobic Baffled Reactor (ABR), Prosiding Seminar Nasional Teknik Kimia UNPAR.

\section{AUTHORS PROFILE}

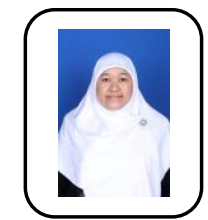

Lulu Nurdini, ST., MT, is a researcher and lecturer in chemical engineering departement, Engineering Faculty, Universitas Jenderal Achmad Yani. Master of Engineering, Institut Teknologi Bandung, 2015. Currently works in enviromental issue and biomass conversion.

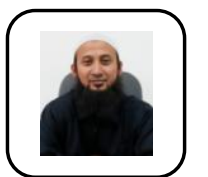

Dr.Hendriyana, is a researcher and lecturer in chemical engineering departement, Engineering Faculty, Universitas Jenderal Achmad Yani. Doctoral degree, Institut Teknologi Bandung, 2016. Currently works in biomass conversion.

W.G. Nur Asti, is a student of chemical engineering departement, Engineering Faculty, Universitas Jenderal Achmad Yani. Doctoral degree, Institut Teknologi Bandung, 2016. Currently works in biomass conversion.

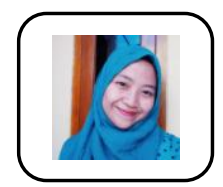

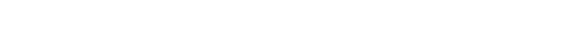

